\title{
Analysis the Role of Private Entities in the Energy Sector of Bangladesh
}

\author{
Mahadehe Hassan \\ Hydrocarbon Unit (HCU), Energy and Mineral Resources Division, Ministry of Power, Energy and Mineral Resources, Dhaka, Bangladesh \\ Email address: \\ mahadehe@hcu.org.bd

\section{To cite this article:} \\ Mahadehe Hassan. Analysis the Role of Private Entities in the Energy Sector of Bangladesh. Journal of Energy, Environmental \& Chemical \\ Engineering. Vol. 6, No. 3, 2021, pp. 76-87. doi: 10.11648/j.jeece.20210603.15
}

Received: August 15, 2021; Accepted: August 27, 2021; Published: September 4, 2021

\begin{abstract}
In the context of globalization and open market economy, there is no alternative to the discovery of energy and mineral resources of Bangladesh and its proper management and planned use. Besides, Bangladesh is committed to the implementation of the Sustainable Development Goals (SDGs) 2030 announced by the United Nations and the government is setting the targets for the implementation of the SDGs in the light of the 8th Five-Year Plan. That is why uninterrupted fuel supply is required. The present government has identified the energy sector as a priority sector, realizing the necessity of energy sector development. The role of private companies is essential to meet the country's growing energy demands as well as to move from a mid-income country to a developed country. Therefore, this study analyzes the role of private entities in the energy sector of Bangladesh The research focuses on the following points: (i) Economic rebound through Covid-19 scenario in Bangladesh; (ii) Contribution of private entities to the energy sector of Bangladesh (iii) Challenges faced by private entities in energy sector of Bangladesh (iv) Prospects of private entities in energy sector of Bangladesh (v) private entities to enhance energy security.
\end{abstract}

Keywords: Energy, Electricity, Role of Private Entities, Economic Growth

\section{Introduction}

The Present government has identified the energy sector as a priority sector realizing the importance of energy sector development. Energy and Mineral Resources Division and its subordinate organization have undertaken various constructive and fruitful activities to achieve full security in the energy sector by achieving the Sustainable Development Goals (SDGs) 2030, Vision-2021 (Middle income Country) and Vision-2041 (Status of a developed Country) working diligently.

The energy sector is a capital-intensive sector. The development of this sector requires a lot of investment. Since development in the public sector along is a difficult task, the Energy and Mineral Resources Division has formulated various policies to involve the private sector in the development of the sector. Notable among these:

1) LPG Bottling Plant Establishment Policy, 2016

2) Liquefied Petroleum Gas (Auto Gas) refueling station and conversion workshop establishment, operation and maintenance policy, 2016
3) Policies for setting up and operating bioethanol plant, 2017

4) Lube Blending plant establishment policy, 2018

5) Private petrochemical plant establishment and management policy, 2019

6) Construction, Import and Supply policy of LNG installation in private sector, 2019

7) Purchase and installation of prepaid/ smart gas meters from open market at residential level policy, 2019

Many non-governmental organizations have been involved in this sector and have been making significant contributions for last 10 (Ten) years

At present 25 (Twenty-five) companies including Bashundhara LP Gas company Ltd, Jamuna LP Gas company Ltd, Omera LP Gas company Ltd, TK LP Gas company Ltd, Orion LP Gas company Ltd, Promita LP Gas company Ltd, Navana LP Gas company Ltd, Sena LP Gas company Ltd, Beximco LP Gas company Ltd, etc. marketing the Liquid petroleum gas (LPG).

Among the top five companies in the lubricants market in Bangladesh are MJL Bangladesh, British Petroleum PLC 
(including Castrol), Total, Caltex and Royal Dutch Shell.

The two companies involved in LNG imports are Summit LNG Terminal Company Limited and Accelerate Energy Bangladesh Limited.

Their combined efforts will play an important role in ensuring energy security of the country

\section{Bangladesh's Economic Rebound Through COVID-19}

\subsection{Bangladesh Economic Performance in COVID-19}

Economic performance GDP growth increased to $8.15 \%$ in FY2018- 2019 from $7.86 \%$ in the previous year on robust growth in industry and services Growth in industry rose from $12.1 \%$ in FY 2018 to $12.7 \%$ in FY 2019, reflecting brisk growth in manufacturing output to supply markedly higher export demand, notably to the US and some previously unpenetrated markets. Growth in services increased from $6.4 \%$ to $6.8 \%$ mainly on improvements in wholesale and retail trade, transport, education, and health and social services. Agriculture growth moderated from $4.2 \%$ to $3.9 \%$. On the demand side, growth in FY 2019 was buoyed by robust growth in exports. Private investment expanded, though at a slower pace than a year earlier, while public investment remained steady. Total investment increased from the equivalent of $31.2 \%$ of GDP in FY 2018 to $31.6 \%$ as private investment increased from $23.3 \%$ of GDP to $23.5 \%$ and public investment remained unchanged at $8.0 \%$. Inflation moderated from $5.8 \%$ in the previous year to average $5.5 \%$ in FY 2019 with lower domestic rice prices following a good harvest and lower food prices on the international market (While food inflation eased, nonfood inflation moved a bit higher owing to upward adjustments in natural gas prices and currency depreciation. Growth in broad money accelerated from 9.2\% in FY 2018 to $9.9 \%$ but remained well below the FY 2019 monetary [2].

After years of steady advances, GDP growth declined in fiscal year 2019-2020 as the COVID-19 pandemic upended economic activity globally. Disruption to supply chains pushed inflation slightly higher but remained under control, and the current account deficit narrowed. Assuming prudent macroeconomic management and proper implementation of timely announced stimulus packages to mitigate the impact of COVID-19, GDP growth is expected to pick up, inflation to moderate, and current account deficit to narrow further in FY 2021 [1].

\subsection{A Resilient Economy with Strong Recovery}

GDP grew by $5.47 \%$ in FY 2020-21, according to preliminary official estimates. This is significantly less than the ADO 2020 projection published in April and down from $8.15 \%$ growth achieved in FY2018-2019. The spread of COVID-19 globally, especially in major trade partners, affect the Bangladesh economy in the final quarter of FY 20192020. Containment measures enforced by the government from 26 March limited the movement of people and goods within the country and across borders, further impairing economic performance. Exports and imports contracted significantly, and remittances, which grew by more than $20 \%$ in the first 8 months, were hit hard in March-May 2020. Moreover, mobility constraints substantially cut back consumer demand. Consumers' uncertainty and lack of confidence scuttled plans for business expansion and investment, further constraining domestic demand [1].

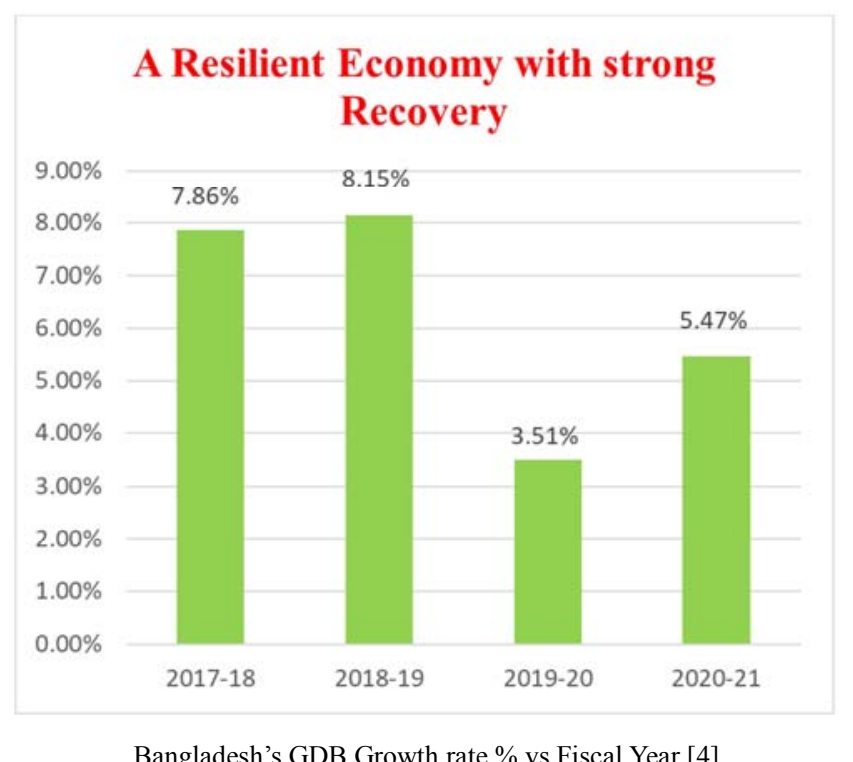

Figure 1. Resilient Economy with strong Recovery.

\subsection{Annual Economic Growth (\$ Billion)}

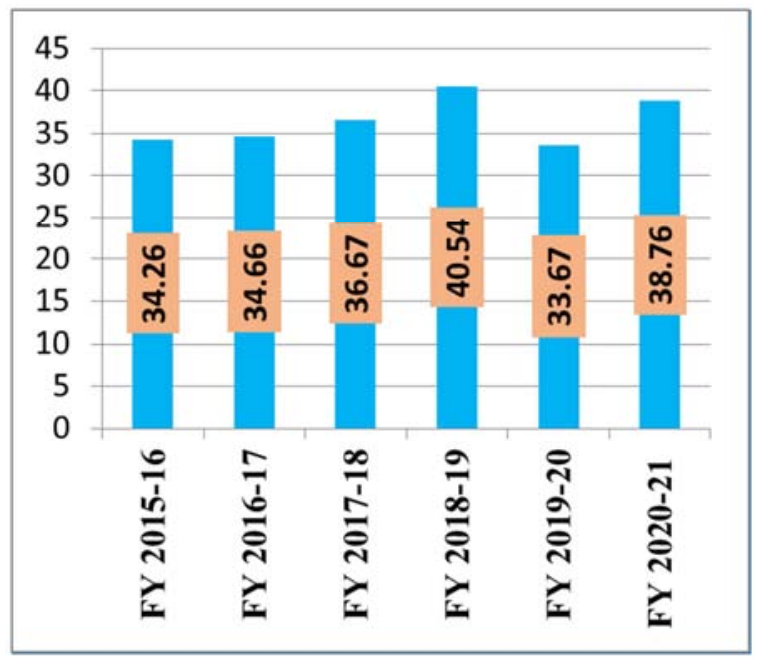

Figure 2. Annual Economic Growth in Bangladesh [5].

Due to the effective measures undertaken by the government of Bangladesh under the dynamic leadership of Honorable Prime Minister Sheikh Hasina:

1) the economy is on track towards making a sharp rebound.

2) industries have been able to achieve $70-80 \%$ recovery despite COVID impact

3) Bangladesh's export earnings have reached USD 33.67 
billion despite its initial decline, it is reached USD 38.76 billion in $2020-2021$

4) the flow of credit to the private sector is slow but it is growing consistently

5) After a long time, Bangladesh's capital market has returned to a bullish trend. aside from the gains in the key index, trading in the country's premier bourse has also seen an upturn, buoyed by renewed optimism among investors

\subsection{Economic Growth in South Asian Countries}

\section{ECONOMIC GROWTH IN SOUTH ASIAN COUNTRIES}

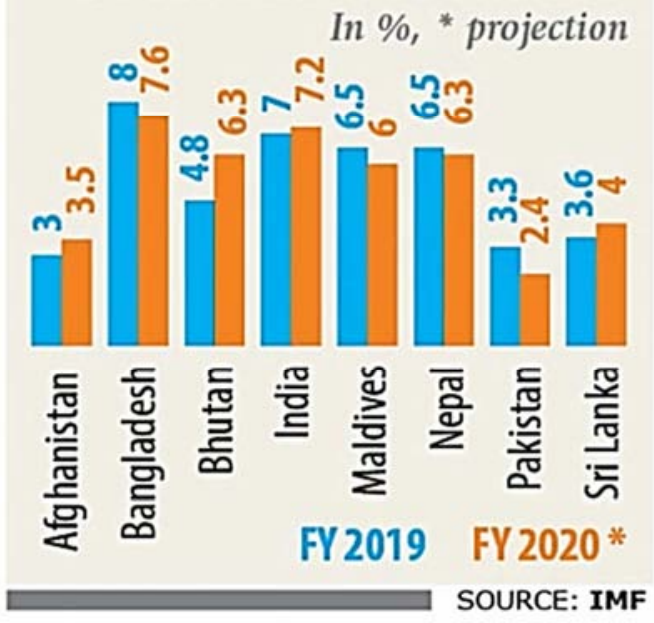

Figure 3. Economic Growth in South Asian Countries [3].

1) The inflow of remittance, which was expected to drop, is now on an upward trajectory

2) Bangladesh bank's foreign currency reserve has crossed $\$ 42$ billion for the first time

3) Bangladesh is currently posting a surplus in its balance of payments resulting low inflation despite huge public spending on infrastructure projects

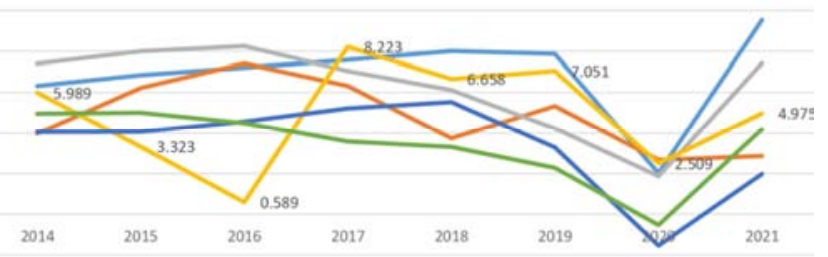

Figure 4. Economic growth in South Asian Countries (2014-2021) [3].

Above Figure shows that the economic growth in all the South Asian countries slumped in 2020; while the economic growth remained positive for most of the countries including Bangladesh, Nepal, Pakistan and Sri Lanka are the two countries that experienced negative economic growth. This erratic fluctuation in economic growth indicates that almost all macroeconomic variables have been affected due to COVID-19 [11].

\section{Contribution of Private Entities to the Energy Sector of Bangladesh}

\subsection{Natural Gas}

Since first discovery in 1955 as of today 26 gas fields, 24 in the onshore and 2 in the offshore have been discovered in the country [7]. Of them 20 gas fields are in production, one offshore gas field have depilated after 14 years of production while other offshore field has not been viable for production due to small reserve. The estimated GIIP (Proven plus Probable) recoverable reserve was 40.09 Tcf. Of them recoverable (Proven plus Probable) 30.06 Tcf [8]. As of June 2021, a total of 18.69 Tcf gas has already been produced leaving only $11.37 \mathrm{TCF}$ recoverable reserve in proven plus probable category [9].

Table 1. At a glance of Natural gas sector in Bangladesh.

\begin{tabular}{ll}
\hline Description & Data \\
\hline Total number of gas fields & 26 \\
Number of gas fields in production & 20 \\
Number of producing wells & 112 \\
Present gas production capacity & $2750 \mathrm{MMCFD}$ \\
Avg. gas production rate & $1744-2752 \mathrm{MMCFD}$ \\
Avg. gas production/day & $2978 \mathrm{MMCFD}$ \\
GIIP (Proven + Probable) Reserve & $40.09 \mathrm{TCF}$ \\
Total recoverable (Proven + Probable) Reserve & $30.06 \mathrm{TCF}$ \\
Cumulative production (June, 2021) & $18.69 \mathrm{TCF}$ \\
Remaining reserve (Proven + Probable) & $11.37 \mathrm{TCF}$ \\
Annual Production by NOC & $299.12 \mathrm{BCF}$ (34\%) \\
Annual Production by IOC & $593.05 \mathrm{BCF}$ (66\%) \\
Present Demand & $3508 \mathrm{MMCFD}$ \\
Present Deficit & $530 \mathrm{MMCFD}$ (along \\
Number of customer & with LNG) \\
\hline
\end{tabular}

Source: HCU Data Bank

Some key information about the historical natural gas production 2009-2021 sector is presented in below:

Historical Production of Gas (2009 10 to 2020-21) in Bcf

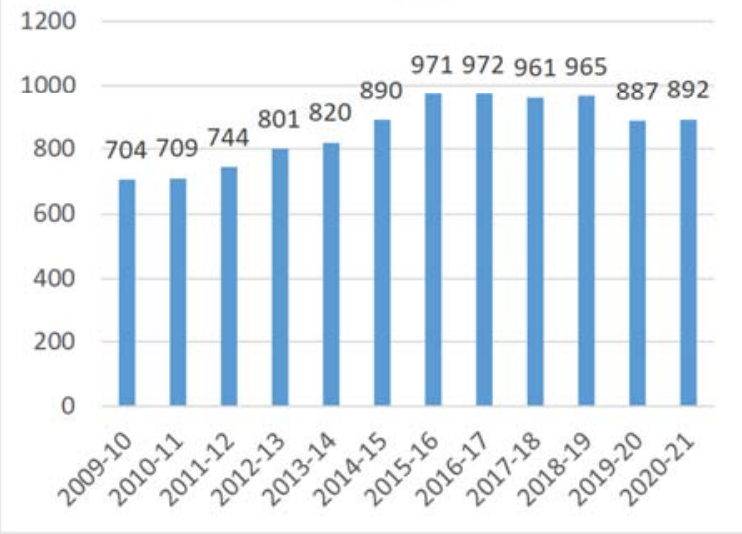

Figure 5. Historical Gas Production in Bangladesh.

Although natural gas was introduced as commercial fuel in 
early 1960s, [7] its consumption got real momentum in eighties marking the beginning of the industrialization in the country.

Table 2. Year-wise Production of Natural Gas by Private companies in Bangladesh.

\begin{tabular}{llll}
\hline Year & Private & Public & Total \\
\hline $2016-2017$ & 582.78 & 389.28 & 972.06 \\
$2017-2018$ & 575.43 & 385.34 & 960.77 \\
$2018-2019$ & 588.64 & 376.10 & 964.74 \\
$2019-2020$ & 559.76 & 327.18 & 886.94 \\
$2020-2021$ & 593.05 & 299.13 & 892.18 \\
\hline
\end{tabular}

Source: HCU Data Bank

Table 3. Year-wise contribution of Private Companies Natural Gas Produced in Bangladesh.

\begin{tabular}{llll}
\hline Year & Private & Public & Total \\
\hline $2016-2017$ & $59.95 \%$ & $40.05 \%$ & $100 \%$ \\
$2017-2018$ & $59.89 \%$ & $40.11 \%$ & $100 \%$ \\
$2018-2019$ & $61.02 \%$ & $38.98 \%$ & $100 \%$ \\
$2019-2020$ & $63.11 \%$ & $36.89 \%$ & $100 \%$ \\
$2020-2021$ & $66.47 \%$ & $33.53 \%$ & $100 \%$ \\
\hline
\end{tabular}

As can be seen from the Table above, Private companies produced $60 \%-66 \%$ of the total Natural Gas in Bangladesh every year. Therefore, the role of private companies in Natural Gas production is very important in the energy sector of Bangladesh.

\subsection{Liquefied Natural Gas (LNG)}

To meet the growing energy demand of the country, the government initiated the import of LNG from abroad. At present, a total of 1000 MMCFD LNG is added to the national grid [12].

Floating LNG Terminal:

1) Agreement with Excelerate Energy, Singapore has been signed for setting up FSRU. Already, floating LNG terminal has been installed in Maheshkhali in Cox's Bazar district. Currently, daily $500 \mathrm{MMcfd}$ re-gasified LNG is added to the national grid by Excelerate Energy.

2) SUMMIT LNG Terminal Co. (Pvt.) Ltd. has signed the Agreement (BOOT) to set up FSRU at Maheshkhali in Cox's Bazar district with a capacity of supplying daily 500 MMcf re-gasified LNG. 500 MMcfd re-gasified LNG is added to the national grid since April 2019.

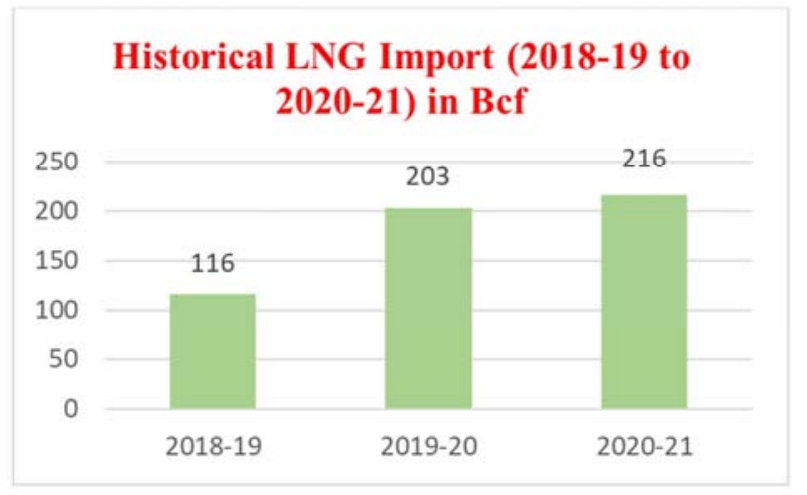

Figure 6. Historical LNG Import in Bangladesh.
Table 4. Year-wise LNG Import in Bangladesh (Bcf).

\begin{tabular}{llll}
\hline Year & MLNG & SLNG & Total \\
\hline $2018-2019$ & 106.03 & 9.85 & 115.89 \\
$2019-2020$ & 102.86 & 100.02 & 202.88 \\
$2020-2021$ & 100.60 & 115.50 & 216.10 \\
\hline
\end{tabular}

Source: HCU Data Bank

Table 5. Year-wise contribution of Private companies LNG Import in Bangladesh.

\begin{tabular}{llll}
\hline Year & MLNG & SLNG & Total \\
\hline $2018-2019$ & $91.49 \%$ & $8.51 \%$ & $100 \%$ \\
$2019-2020$ & $50.70 \%$ & $49.30 \%$ & $100 \%$ \\
$2020-2021$ & $46.55 \%$ & $53.45 \%$ & $100 \%$ \\
\hline
\end{tabular}

As can be seen from the Table above, in the Fiscal Years 2018-2019, 2019-2020 and 2020-2021 Excelerate Energy company imported $91.49 \%, 50.70 \%$ and $46.55 \%$ of the total Liquefied Natural Gas (LNG) and SUMMIT LNG Terminal Co. (Pvt.) Ltd imported 8.51\%, 49.30\% and 53.45\%. Therefore, the role of private companies in Liquefied Natural Gas (LNG) import is very important in the energy sector of Bangladesh

\subsection{Liquefied Petroleum Gas (LPG)}

Liquefied Petroleum Gas (LPG) is a burning fuel derived from condensates or crude oil (gas fields/ refineries) widely used as a green fuel for cooking, heating, industrial applications, automotive sector \& plastic production etc. LPG is an alternative to burning wood \& kerosene, this promotes afforestation \& clean kitchens safer to use than natural gas, $\mathrm{CNG}$ or kerosene. It is mixture of Propane \& Butane (c3 \& c4) \& its calorific value ( 46.1 mj/kg).

At Present Liquefied Petroleum Gas (LPG) is being used everywhere in Bangladesh:

1) Cooking fuel for households \& residential townships

2) Cooking fuel for hotels, commercial establishments, cafes \& restaurants

3) Heating \& burning fuel for small to large scale industry

4) Fuel for captive power generation

5) Automotive fuel (Auto gas) as an alternate to $\mathrm{CNG}$

6) Fuel for aiding Construction \& Shipyards (welding, heating, etc.)

7) Reticulation system (LP gas supply by pipeline)

Table 6. Current Scenario of Bangladesh LPG Market [13].

\begin{tabular}{ll}
\hline Description & Data \\
\hline 2020-21 Local LPG Production & $0.92 \%$ \\
Local Producers & ERL and RPGCL \\
2020-21 LPG Import & $99.08 \%$ \\
Import Terminals & 20 Nos \\
Dealers & 3,000 Nos \\
Retailers & 38,000 Nos \\
LPG cylinders in market & 30,000000 Nos \\
2019-20 Bangladesh LPG Import volume & $835,027 \mathrm{MT}$ \\
2020-21 Bangladesh LPG Import volume & $14,27,826 \mathrm{MT}$ \\
Market growth rate & $14.6 \%$ \\
\hline
\end{tabular}

Source: HCU Data Bank 
Table 7. LPG scenario of last 5 year (MT).

\begin{tabular}{llll}
\hline Year & Production & Import & Total \\
\hline $2014-15$ & 17,574 & 110,000 & 127,574 \\
$2015-16$ & 14,000 & 172,792 & 186,792 \\
$2016-17$ & 16,382 & 307,000 & 323,382 \\
$2017-18$ & 15,936 & 537,686 & 553,622 \\
$2018-19$ & 19,228 & 681,036 & 700,264 \\
$2019-20$ & 13,414 & 835,027 & 848,441 \\
$2020-21$ & 13,207 & $1,427,826$ & $1,441,033$ \\
\hline
\end{tabular}

Source: HCU Data Bank

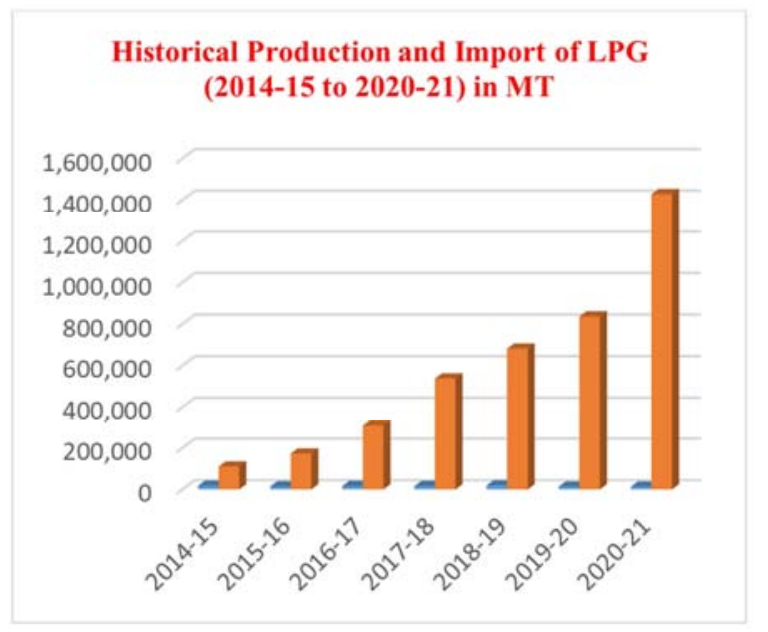

Figure 7. Historical Production and Import of LPG Private and Public companies in Bangladesh.

Table 8. Market Scenario of LPG Consumption, FY 2020-21.

\begin{tabular}{lll}
\hline No. & Items & Amount (MT) \\
\hline 1 & Domestic & $1,224,878.00$ \\
2 & Industrial & $14,410.00$ \\
3 & Commercial & $129,693.00$ \\
4 & Auto gas & $72,052.00$ \\
Total & & $1,441,033.00$ \\
\hline
\end{tabular}

Source: HCU Data Bank

\section{Market Scenario of LPG Consumption, FY 2020-2021 (in MT)}

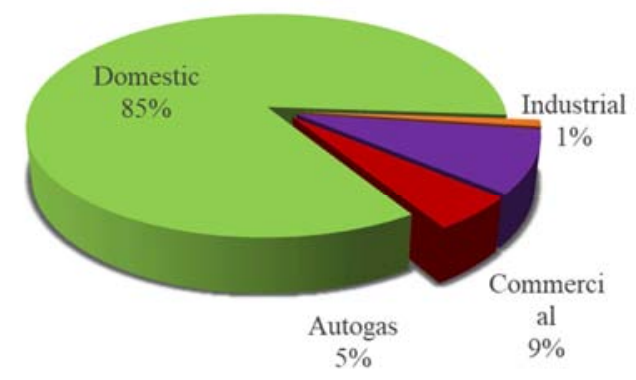

Figure 8. Consumption of LPG Market Scenario in Bangladesh 2020-2021.

Industrial Purpose:

1) Ceramic Industry

2) Motor Cycle Industry

3) Bicycle Industry
4) Steel Industry [Preheating Unit of BSRM, KSRM etc.]

5) Insulating Foam (For Steel Structures) producing plant

6) Tea Processing Plant

7) Aerosol Industry

Commercial Purpose
1) Hotel
2) Restaurant
3) Condominium

Table 9. Year-wise contribution of Private companies LPG Import in Bangladesh.

\begin{tabular}{llll}
\hline Year & Public & Private & Total \\
\hline $2014-2015$ & $13.78 \%$ & $86.22 \%$ & $100 \%$ \\
$2015-2016$ & $7.49 \%$ & $92.51 \%$ & $100 \%$ \\
$2016-2017$ & $4.07 \%$ & $94.93 \%$ & $100 \%$ \\
$2017-2018$ & $2.88 \%$ & $97.12 \%$ & $100 \%$ \\
$2018-2019$ & $2.75 \%$ & $97.25 \%$ & $100 \%$ \\
$2019-2020$ & $1.58 \%$ & $98.42 \%$ & $100 \%$ \\
$2020-2021$ & $0.92 \%$ & $99.08 \%$ & $100 \%$ \\
\hline
\end{tabular}

As can be seen from the Table above, in the Fiscal Years 2014-205, 2015-2016, 2016-2017, 2017-2018, 2018-2019, 2019-2020 and 2020-2021 Private companies imported $86.22 \%, 92.81 \% 94.93 \%, 97.12 \%, 97.25 \%, 98.42 \%$ and 99.08\% of the total Liquefied Petroleum Gas (LPG) and Public Company produced 13.75\%, 7.49\%, 4.07\%, 2.88\%, $2.75 \% 1.58 \%$ and $0.92 \%$. Therefore, the role of Private companies in the import of Liquefied Petroleum Gas (LPG) is very important in the energy sector of Bangladesh.

\subsection{Lubricating Oil}

Market Scenario of lubricating oil in Bangladesh

Total Market Size of lubricating oil in Bangladesh: $~ 130$ million liters (2019) \& monetary value around: BDT 3,500 core. Major users of lubricating oil in Bangladesh:

(i) Automobile sector

(ii) Industrial sector

(iii) Power Plants

(iv) Agriculture Sector

(v) Marine sector

The Bangladesh lubricants market expected growth is around $3 \%$ per annum

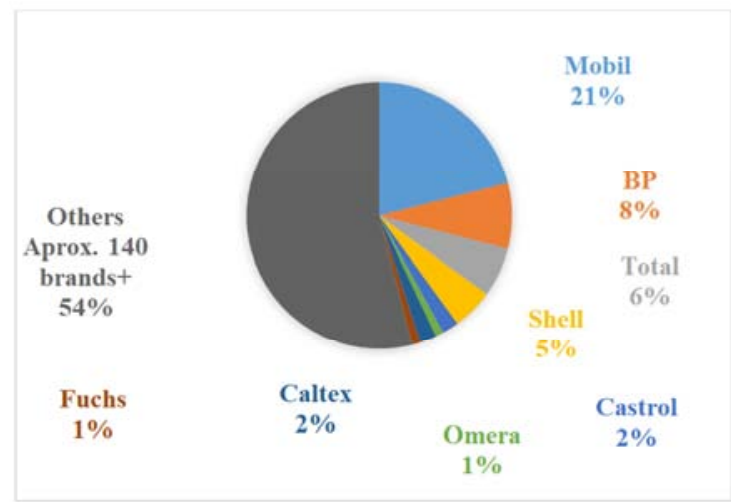

Figure 9. Market Share of lubricating oil in Bangladesh Contribution of Private Sector. 
Marketing Companies of Bangladesh Petroleum corporation (BPC)

(i) Meghna petroleum limited.

(ii) Jmuna oil company limited.

(iii)Padma oil company limited.

(iv) Standard Asiatic oil company limited.

(v) Eastern lubricants blenders limited (blenders only)

State owned companies are marketing the following Brands
(i) Mobil
(ii) $\mathrm{BP}$
(iii) Total
(iv) Omera Lubricants
(v) Castrol
(vi) Lukoil
(vii) Meghna
(viii) Q8
(ix) Jamuna etc

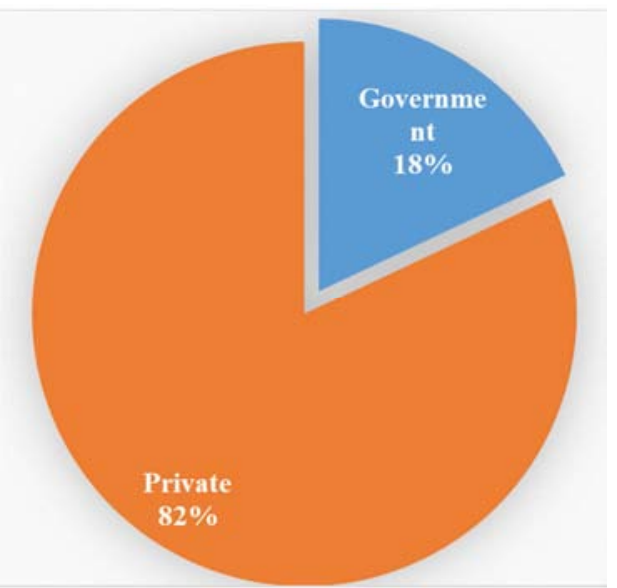

Figure 10. Contribution of Private and Public companies in Bangladesh.

\section{Lube oil Blenders \& Blending Capacity:}

Table 10. Public and Private Companies Lube Oil Blenders \& Blending Capacity in Bangladesh.

\begin{tabular}{lll}
\hline Name of Lube Blenders & Brand & $\begin{array}{l}\text { Capacity } \\
\text { (MT) }\end{array}$ \\
\hline $\begin{array}{l}\text { MJL Bangladesh Limited } \\
\text { Eastern Lubricant Blenders Ltd }\end{array}$ & Mobil/Omera & 50,000 \\
(Public) & JOCL/MPL/POCL & 25,000 \\
Sigma oil Industries Ltd & Soil & 25,000 \\
Global Oil Co. Ltd & AP & 20,000 \\
City Oil industries Limited & Amirath & 20,000 \\
Lub-rref Bangladesh Limited & BNO & 20,000 \\
Standard Asiatic Oil Co Ltd (Public) & JOCL/MPL/POCL & 18,000 \\
Sha Aminullah Oil Agency Ltd & Boss & 15,000 \\
Lube House Limited & National & 15,000 \\
Pacific Oil Co. Limited & Sino & 12,000 \\
Lubricant Asia Ltd & Fuchs & 12,000 \\
Ric Lubricants Ltd & Kings & 12,000 \\
Al Haj Abdul Kuddus Ltd & J1 & 10,000 \\
Mega Lubricants Ltd & Mega/RFL & 10,000 \\
Oriental oil Co Limited & Orient & 10,000 \\
Min oils Ltd & Min & 5,000 \\
Total & & 279,000 \\
\hline
\end{tabular}

Table 11. Contribution of Private Companies Lube Oil Blenders \& Blending Capacity in Bangladesh.

\begin{tabular}{lll}
\hline Private & Public & Total \\
\hline $84.59 \%$ & $15.41 \%$ & $100 \%$ \\
\hline
\end{tabular}

As can be seen from the Figure and Table above, Private companies imported $82 \%$ per annum with a Capacity $84.59 \%$ of the total Lubricating Oil and the Public Companies imported $18 \%$ per annum with a capacity $15.41 \%$ Therefore, the role of private companies in the import of Lubricating Oil is very important in the energy sector of Bangladesh.

\subsection{Furnace Oil}

Bangladesh High Sulphur furnace oil (HSFO), 180/380 CST furnace oil is imported. The major users of imported furnace oil consume $43 \%$ of total furnace oil imports from HSFO fired power plants (5,724 MW). The Eastern Refinery limited (ERL) also produce furnace oil private power producers are allowed to import fuel oil for their own power plant consumption since $2011 \&$ the consumption is increasing gradually.

Table 12. Public and Private Companies High Sulphur furnace oil (HSFO) Storage Capacity in Bangladesh (MT).

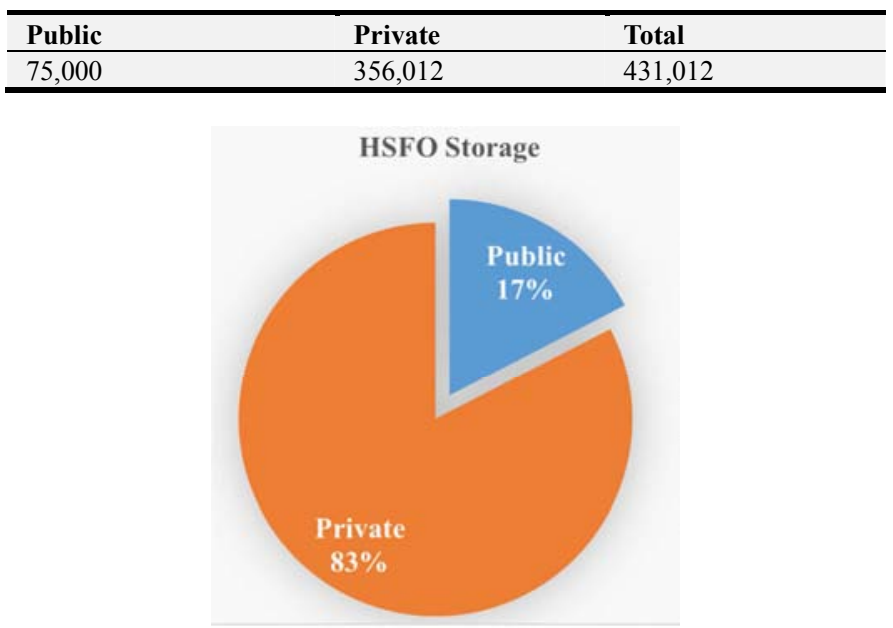

Figure 11. Contribution of HSFO storage capacity of Private and Public companies in Bangladesh.

Table 13. Furnace oil scenario of last 4 years (in Ton).

\begin{tabular}{llll}
\hline FY & Public & Private & Total \\
\hline $2017-2018$ & 343129.00 & 1056470.85 & $1,399,599.85$ \\
$2018-2019$ & 274915.00 & 1658028.88 & $1,932,943.88$ \\
$2019-2020$ & 22852.00 & 2385007.00 & $2,407,859.00$ \\
$2020-2021$ & 70736.50 & 2623932.03 & $2,694,668.53$ \\
\hline
\end{tabular}

Source: HCU Data Bank

Table 14. Year-wise contribution of Private Companies Furnace Oil Import in Bangladesh.

\begin{tabular}{llll}
\hline Financial Year & Public & Private & Total \\
\hline $2015-2016$ & $18.62 \%$ & $81.38 \%$ & $100 \%$ \\
$2016-2017$ & $23.69 \%$ & $76.31 \%$ & $100 \%$ \\
$2017-2018$ & $24.52 \%$ & $75.48 \%$ & $100 \%$ \\
$2018-2019$ & $14.22 \%$ & $85.78 \%$ & $100 \%$ \\
$2019-2020$ & $0.95 \%$ & $99.05 \%$ & $100 \%$ \\
$2020-2021$ & $2.62 \%$ & $97.38 \%$ & $100 \%$ \\
\hline
\end{tabular}


As can be seen from the Table above, in the Fiscal Years 2015-2016, 2016-2017, 2017-2018, 2018-2019, 2019-2020 and 2020-2021 Private companies imported $81.36 \%, 76.31 \%$ $75.48 \%, 85.78 \%, 99.05 \%$ and $97.38 \%$ of the total furnace oil and Public Companies imported 18.62\%, 23.69\%, 24.52\%, $14.22 \%, 0.95 \%$ and $2.62 \%$. Therefore, the role of private companies in the import of Furnace Oils is very important in the energy sector of Bangladesh.

\subsection{Private Entities Bitumen, Transformer Oil, Greases \& Additives}

\section{Bitumen:}

Bangladesh is moving towards heavy development of industries \& infrastructure for better road connectivity, new roads are under construction $\&$ the demand for good quality bitumen is increasing current annual demand of Bitumen is $\sim 500,000 \mathrm{MT}$, out of which $\sim 70,000 \mathrm{MT}$ is supplied by ERL $\&$ rest of the amount is being imported by private companies in the year 2020, Bashundhara oil \& gas, a private company, launched a Bitumen production plant, with an installed capacity of 900,000 MT per annum to meet country's growing demand of Bitumen,

Transformer oil

Private entities have also manifested their footprint in producing transformer oil locally that contribute exceedingly to the power sector of Bangladesh.

Grease

Private entities of Bangladesh also produce greases of many grades to support automobile \& industrial sector of Bangladesh.

Additives

MJL also set up additives manufacturing facilities, the first of its kind in this country.

\subsection{Refinery Oil}

Table 15. Refinery Oil scenario of last 4 years (in Ton).

\begin{tabular}{llll}
\hline FY & Public & Private & Total \\
\hline $2017-2018$ & 3796314.00 & 45001.52 & $3,841,315.52$ \\
$2018-2019$ & 3953285.00 & 94924.00 & $4,048,209.00$ \\
$2019-2020$ & 3986719.00 & 322667.06 & $4,309,386.06$ \\
$2020-2021$ & 4188558.39 & 156400.45 & $4,344,958.84$ \\
\hline
\end{tabular}

Source: HCU Data Bank

Table 16. Year-wise contribution of Private Companies Refinery oil imports in Bangladesh.

\begin{tabular}{llll}
\hline Financial Year & Public & Private & Total \\
\hline $2017-2018$ & $98.83 \%$ & $1.17 \%$ & $100 \%$ \\
$2018-2019$ & $97.65 \%$ & $2.35 \%$ & $100 \%$ \\
$2019-2020$ & $92.51 \%$ & $7.49 \%$ & $100 \%$ \\
$2020-2021$ & $96.40 \%$ & $3.60 \%$ & $100 \%$ \\
\hline
\end{tabular}

As can be seen from the Table above, in the Fiscal Years 2017-2018, 2018-2019, 2019-2020 and 2020-2021, Private Companies imported $1.17 \%, 2.35 \% 7.49 \%$ and $3.620 \%$ of the total refinery oil and Public Companies imported 98.83\%, $97.65 \%, 92.51 \%$ and $96.40 \%$. Therefore, the role of private companies in the import of refinery oil is very important in the energy sector of Bangladesh

\subsection{Crude Oil}

Table 17. Crude oil scenario of last 4 years (in Ton).

\begin{tabular}{llll}
\hline FY & Public & Private & Total \\
\hline $2017-2018$ & 1079598.00 & 129143.80 & $1,208,741.80$ \\
$2018-2019$ & 1166428.00 & 218635.56 & $1,385,063.56$ \\
$2019-2020$ & 1256130.00 & 5995.00 & $1,262,125.00$ \\
$2020-2021$ & 1307261.92 & 123123.00 & $1,430,384.92$ \\
\hline
\end{tabular}

Source: HCU Data Bank

Table 18. Year-wise contribution of Private Companies Crude oil import in Bangladesh.

\begin{tabular}{llll}
\hline Financial Year & Public & Private & Total \\
\hline $2017-2018$ & $89.32 \%$ & $10.68 \%$ & $100 \%$ \\
$2018-2019$ & $84.21 \%$ & $15.79 \%$ & $100 \%$ \\
$2019-2020$ & $99.52 \%$ & $0.48 \%$ & $100 \%$ \\
$2020-2021$ & $91.39 \%$ & $8.61 \%$ & $100 \%$ \\
\hline
\end{tabular}

As can be seen from the Table above, in the Fiscal Years 2017-2018, 2018-2019, 2019-2020 and 2020-2021, Private Companies imported $10.68 \%, 15.79 \%, 0.48 \%$ and $8.61 \%$ of the total crude oil and Public Company imported $89.32 \%$, $84.21 \%, 99.52 \%$ and $91.39 \%$. Therefore, the role of private companies in the import of Crude Oil is very important in the energy sector of Bangladesh.

\subsection{Coal}

Table 19. Coal scenario of last 6 year (MT).

\begin{tabular}{llll}
\hline Year & Public (Production) & Import (Private) & Total \\
\hline $2015-16$ & $1,021,638.00$ & $3,812,060.00$ & $4,833,698.00$ \\
$2016-17$ & $1,160,657.81$ & $2,801,407.00$ & $3,962,065.00$ \\
$2017-18$ & $923,276.00$ & $3,394,534.24$ & $4,317,810.00$ \\
$2018-19$ & $803,315.00$ & $5,754,025.00$ & $65,57,339.00$ \\
$2019-20$ & $808,358.00$ & $6,828,032.00$ & $7,636,390.00$ \\
$2020-2021$ & $753,973.00$ & $6,751,041.00$ & $7,505,014.00$ \\
\hline
\end{tabular}

Source: HCU Data Bank

Table 20. Year-wise contribution of Private Companies Coal Import in Bangladesh.

\begin{tabular}{llll}
\hline Financial Year & Public & Private & Total \\
\hline $2015-2016$ & $21.14 \%$ & $78.86 \%$ & $100 \%$ \\
$2016-2017$ & $29.29 \%$ & $70.71 \%$ & $100 \%$ \\
$2017-2018$ & $21.38 \%$ & $78.62 \%$ & $100 \%$ \\
$2018-2019$ & $12.25 \%$ & $87.75 \%$ & $100 \%$ \\
$2019-2020$ & $10.59 \%$ & $89.41 \%$ & $100 \%$ \\
$2020-2021$ & $10.05 \%$ & $89.95 \%$ & $100 \%$ \\
\hline
\end{tabular}

As can be seen from the Table above, in the Fiscal Years 2015-2016, 2016-2017, 2017-2018, 2018-2019, 2019-2020 and 2020-2021 Private Companies imported 78.86\%, 70.71\% $78.62 \%, 87.75 \%, 89.41 \%$ and $89.95 \%$ of the total coal and Public Company Produced $21.41 \%, 29.29 \%, 21.38 \%$, $12.25 \%, 10.59 \%$ and $10.05 \%$. Therefore, the role of private companies in the import of coal is very important in the energy sector of Bangladesh. 


\subsection{Electricity}

Table 21. Public and Private Companies Electricity Installation Capacity in Bangladesh (MW) [10].

\begin{tabular}{lll}
\hline Public & Private & Total \\
\hline 10,339 & 10,044 & 20,383 \\
\hline
\end{tabular}

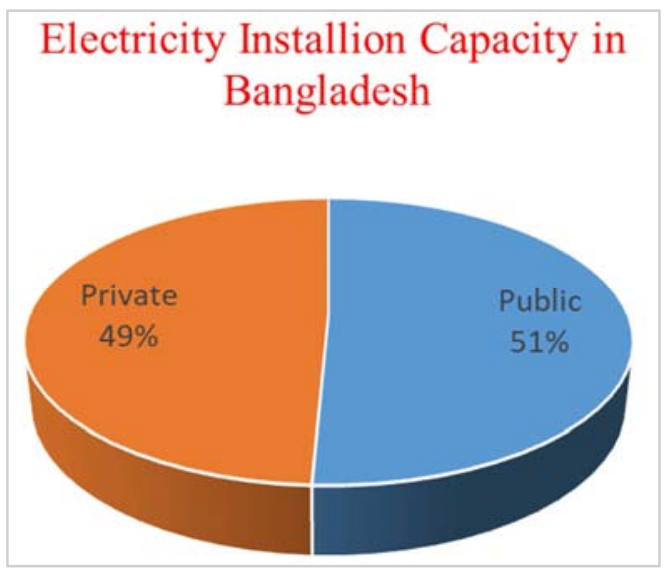

Figure 12. Electricity Installation capacity in Bangladesh.

Table 22. Electricity generation scenario of last 5 years in Bangladesh (Ghr) [10].

\begin{tabular}{llll}
\hline Financial Year & Public & Private & Total \\
\hline $2015-2016$ & 22585 & 29608 & 52193 \\
$2016-2017$ & 26597 & 30679 & 52276 \\
$2017-2018$ & 31082 & 31595 & 62677 \\
$2018-2019$ & 35107 & 35426 & 70553 \\
$2019-2020$ & 35316 & 36102 & 71419 \\
\hline
\end{tabular}

Table 23. Year-wise contribution of Private Companies Electricity generation in Bangladesh.

\begin{tabular}{llll}
\hline Financial Year & Public & Private & Total \\
\hline $2015-2016$ & $43.27 \%$ & $56.73 \%$ & $100 \%$ \\
$2016-2017$ & $50.88 \%$ & $49.12 \%$ & $100 \%$ \\
$2017-2018$ & $49.59 \%$ & $50.41 \%$ & $100 \%$ \\
$2018-2019$ & $49.77 \%$ & $50.23 \%$ & $100 \%$ \\
$2019-2020$ & $49.45 \%$ & $50.55 \%$ & $100 \%$ \\
\hline
\end{tabular}

Table 24. Year-wise Maximum Electricity generation in Bangladesh (MW) [10].

\begin{tabular}{llll}
\hline Financial Year & East Zone & West Zone & Total \\
\hline $2015-2016$ & 6699 & 2337 & 9036 \\
$2016-2017$ & 7024 & 2455 & 9479 \\
$2017-2018$ & 8034 & 2924 & 10958 \\
$2018-2019$ & 9012 & 3881 & 12893 \\
$2019-2020$ & 9005 & 3733 & 12738 \\
\hline
\end{tabular}

As can be seen from the Table above, in the Fiscal Years 2015-2016, 2016-2017, 2017-2018, 2018-2019 and 20192020 Private companies produced $56.73 \%$, 49.12\% 50.41\%, $50.23 \%$, and $50.55 \%$ of the total Electricity Generation and Public Company Produced 43.27\%, 50.88\%, 49.59\%, $49.77 \%$, and $49.45 \%$ Therefore, the role of private companies in the produce of Electricity generation is very important in the energy sector of Bangladesh.

\section{Result and Discussion}

\subsection{The amount of Contribution of Private Entities in the Energy Sector of Bangladesh}

Table 25. Contribution of Private Entities in the Energy Sector of Bangladesh in the FY 2017-2018.

\begin{tabular}{lll}
\hline Item Name & Public & Private \\
\hline Natural Gas & $40.11 \%$ & $59.89 \%$ \\
LNG & - & - \\
LPG & $2.88 \%$ & $97.12 \%$ \\
Lubricating Oil & $18.00 \%$ & $82.00 \%$ \\
Furnace oil & $24.52 \%$ & $75.48 \%$ \\
Refinery oil & $98.83 \%$ & $1.17 \%$ \\
Crude oil & $89.32 \%$ & $10.68 \%$ \\
Coal & $21.38 \%$ & $78.62 \%$ \\
Electricity & $49.59 \%$ & $50.41 \%$ \\
\hline
\end{tabular}

Table 26. Contribution of Private Entities in the Energy Sector of Bangladesh in the FY 2018-2019.

\begin{tabular}{lll}
\hline Item Name & Public & Private \\
\hline Natural Gas & $38.98 \%$ & $61.02 \%$ \\
LNG & $0 \%$ & $100 \%$ \\
LPG & $2.75 \%$ & $97.25 \%$ \\
Lubricating Oil & $18.00 \%$ & $82.00 \%$ \\
Furnace oil & $14.22 \%$ & $85.78 \%$ \\
Refinery oil & $97.65 \%$ & $2.35 \%$ \\
Crude oil & $84.21 \%$ & $15.79 \%$ \\
Coal & $12.25 \%$ & $78.62 \%$ \\
Electricity & $49.77 \%$ & $50.23 \%$ \\
\hline
\end{tabular}

Table 27. Contribution of Private Entities in the Energy Sector of Bangladesh in the FY 2019-2020.

\begin{tabular}{lll}
\hline Item Name & Public & Private \\
\hline Natural Gas & $36.89 \%$ & $63.11 \%$ \\
LNG & $0 \%$ & $100 \%$ \\
LPG & $1.58 \%$ & $98.42 \%$ \\
Lubricating Oil & $18.00 \%$ & $8.002 \%$ \\
Furnace oil & $0.95 \%$ & $99.05 \%$ \\
Refinery oil & $92.51 \%$ & $7.49 \%$ \\
Crude oil & $99.52 \%$ & $0.48 \%$ \\
Coal & $10.59 \%$ & $89.41 \%$ \\
Electricity & $49.45 \%$ & $50.55 \%$ \\
\hline
\end{tabular}

Table 28. Contribution of Private Entities in the Energy Sector of Bangladesh in the FY 2020-2021.

\begin{tabular}{lll}
\hline Item Name & Public & Private \\
\hline Natural Gas & $33.53 \%$ & $66.47 \%$ \\
LNG & $0 \%$ & $100 \%$ \\
LPG & $0.92 \%$ & $99.08 \%$ \\
Lubricating Oil & $18.00 \%$ & $82.00 \%$ \\
Furnace oil & $2.62 \%$ & $97.38 \%$ \\
Refinery oil & $96.40 \%$ & $3.60 \%$ \\
Crude oil & $91.39 \%$ & $8.61 \%$ \\
Coal & $10.05 \%$ & $89.95 \%$ \\
\hline
\end{tabular}

\subsection{Opportunities of Investment in Natural Gas Sector in Bangladesh}

Gas exploration activities need to be boosted both in onshore \& offshore. Transmission \& Distribution networks of natural gas are yet to cover entire Bangladesh so the natural gas transmission \& distribution infrastructure will need overhauling \& upgradation in next few years. 
New technologies available in the international market will need to be adapted in Bangladesh (IOT, Remote Metering \& internet billing). Natural gas transmission \& distribution are yet to have participation from local private entities. So initiative is required for the mandatory participation of local private sector in pipeline construction, ownership, operation and maintenance. This will help to build capacity $\&$ transfer technology.

Local private entities can also engage in construction \& maintenance of cross border gas pipeline. Foreign investors, in case of participation in gas transmission, have to join hands with local entities. Preference to be given to local private entities to access finance for natural gas infrastructure development. Private companies, by PPP boot (build, own, operate, transfer) or on independent basis, can build the infrastructure required for gas pipeline network to supply natural gas to economic zones. Private companies can set up dedicated pipeline network \& distribution facility for economic zones \& ensure uninterrupted natural gas supply.

Private companies can also actively participate in natural gas marketing \& infrastructure maintenance. In Canada privately owned companies such as perk land fuel corporation, husky energy etc. are successfully owning \& operating natural gas transmission \& distribution line. Bangladesh's natural gas/ pipe gas usage need to be optimized \& routed to productive sectors only (power generation \& fertilizer industries). The government of Bangladesh, through policy encouraging LPG for commercial, domestic \& automotive segments and domestic gas connection \& use of CNG need to be discouraged.

\subsection{Opportunities of Investment of LNG in Bangladesh}

The Bay of Bengal has rough seas during the monsoon period, this leads to interruption in supply of LNG from the present two FSRUS. also, the government incurs capacity charge during that time. Globally, FSRU units are expensive to operate \& maintain. they are used as temporary infrastructure to bridge peak gas demand and to reduce cost $\&$ to ensure consistent supply of LNG over 365 days each year, a land based LNG terminal in deep sea port is required,

However, proposed deep sea port is still in project phase \& will not be operational before 2024. As a result of LNG retailing policy, private importers can import and market LNG by themselves. Private companies can find out suitable locations/lands (with riverine access) for setting up and operating small scale LNG terminals (SSLNG).

Based on capability of private companies, government should create and facilitate access to those lands. Petrobangla can buy the LNG \& pass back to private companies for retailing which in turn creates revenue for Bangladesh government as well. However, the LNG import prices in different LNG terminals will not be the same (land based terminal, FSRUS \& small scale). Government should address this issue while negotiating capacity cost of different LNG infrastructure proposals.

\subsection{Opportunities of Investment in Petrochemical Industries in Bangladesh}

Demand of industrial sectors such as automobile, electronics, construction, packing, consumer goods (cosmetic) are on the rise to produce the raw materials such as HDPE, LDPE, LLDPE, PVC, PP, BR etc., industries require various petrochemical products such as benzene, butadiene, ethylene, xylene, propylene etc. Considering the burgeoning demand of petrochemical products in Bangladesh, this industry has a strong prospect in the days to come. Therefore, setting up a petrochemical industry in deep-sea ports like matarbari and chattogram bay terminal will be a potential source of national revenue and augment the energy sector.

\subsection{Fuel-wise Composition of Power Development Plan (MW) and Oil Demand and Supply Projection for Non Power Sector}

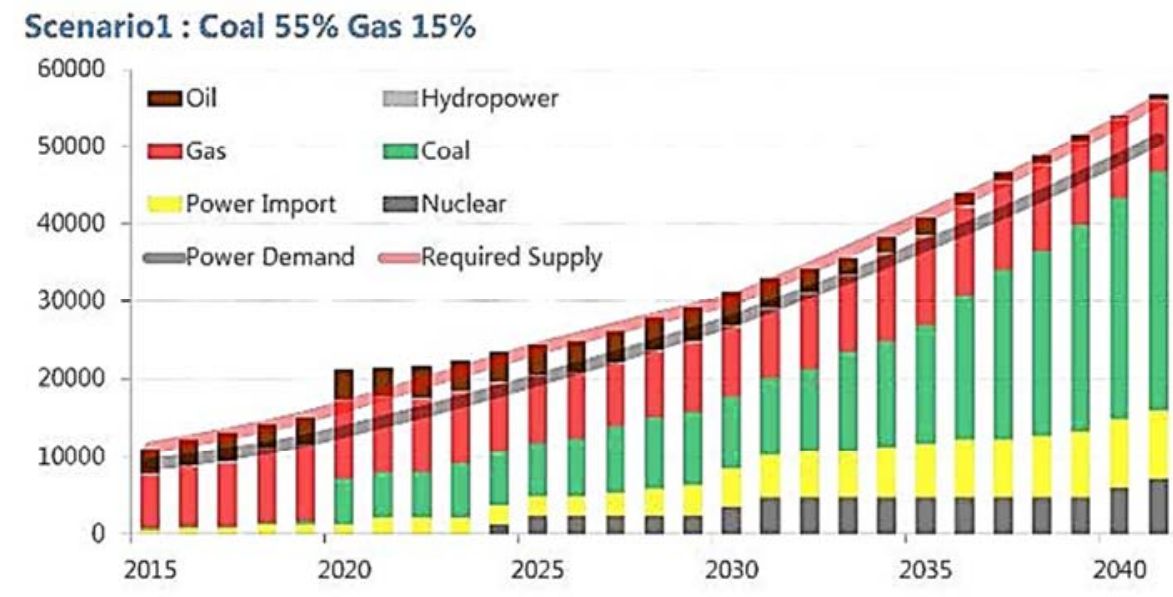

Figure 13. Fuel-wise composition of power development Plan [6]. 


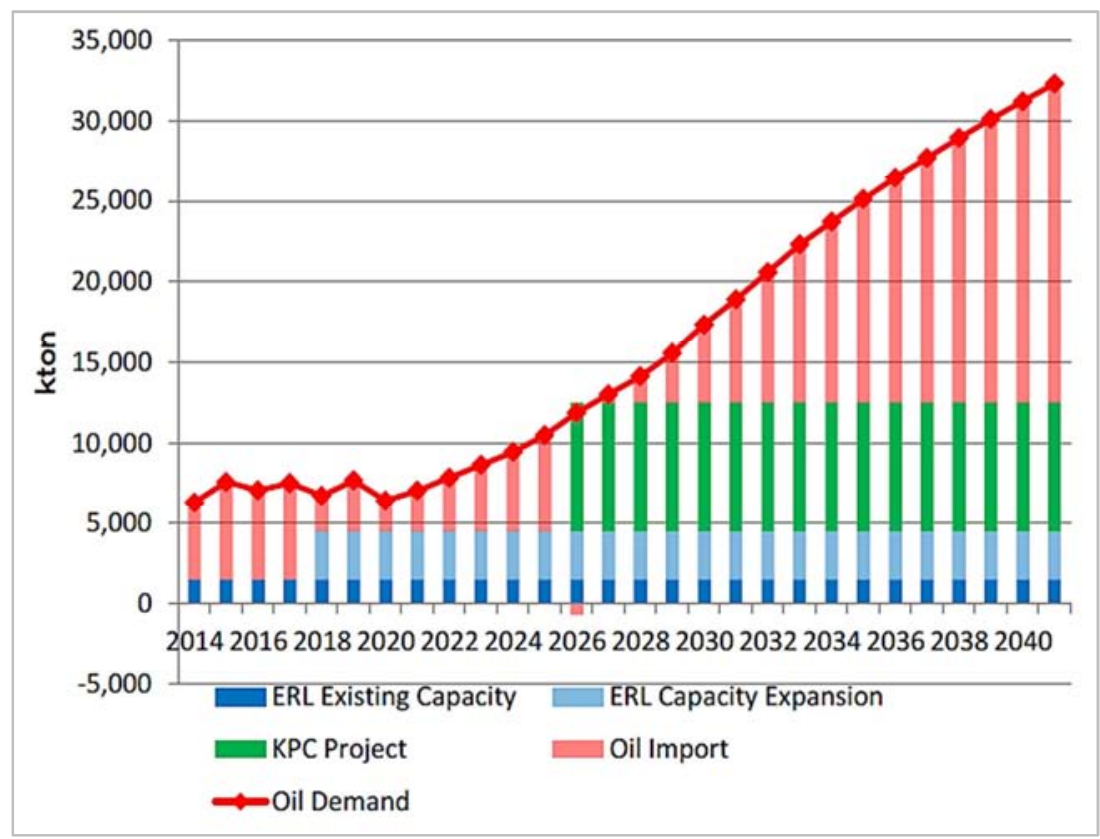

Figure 14. Bangladesh oil demand \& supply projection [6].

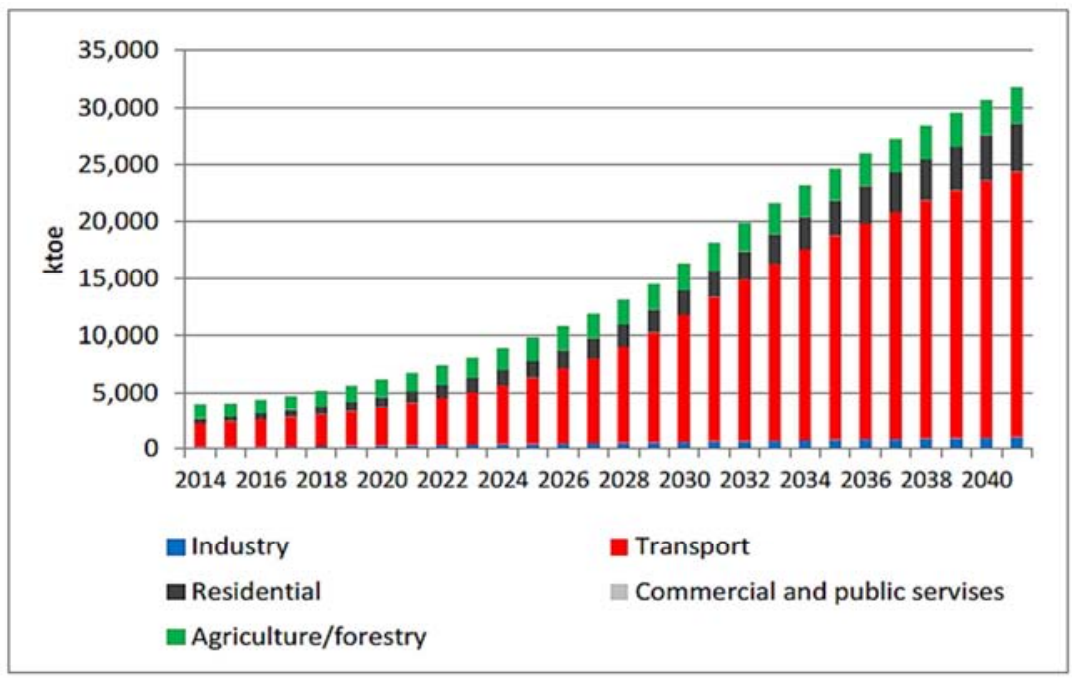

Figure 15. Oil demand projection for Non-power sectors [6].

\section{Challenges Faced by Private Entities in Energy Sector of Bangladesh}

Counterfeit/adulterated products have been a big concern area for the lubricants industry

1) Monitoring \& enforcement of law for violation is mandatory

2) Re-cycled oil - extraction through conventional filtration of used lubricants, has to be stopped

3) The permission to blend \& import finished products must require fulfillment of conditions like blending agreements with renowned oil companies \& standardization prior to import

4) We have now many blenders $\&$ importers $\&$ more than $50 \%$ of the market is dominated by low end products which are damaging expensive industries \& vehicles
5) Bangladesh is allowing to produce/market very lowquality grade which are globally obsolete (i.e., API SC/CC) since the year 1967

6) Multiple regulators

7) Duplication of Licensing fees by BERC/BPC

8) High import cost of raw materials for LPG cylinders

9) Unhealthy practices such as cross filling of LPG cylinders

10)Strengthening of supervision \& enforcement by Department of Explosives

11)Unable to receive large $L P G$ vessels due to lack of port infrastructure \& low water depth

12)Small LPG companies (in terms of infrastructure \& market share) do not maintain standard industry practices \& safety guidelines 


\section{Conclusion}

Bangladesh will have to take following steps with top priority to maintain its wheel of growth by creating adequate energy security: (i) The petroleum act 1974/ BPC ordinance needs to be unbundle/amendment; (ii) Investment at home \& abroad will have to be building Hydrocarbon Reserve; (iii) Investment in infrastructure like development of deep-sea ports at matarbari (moheshkhali) \& chattogram bay terminal these can be hubs for all types of liquid products import which will eventually make the product cost competitive; (iv) We need to be remain competitive in production \& service sector; (v) Petrochemical import terminal need to be set up for the production of chemicals such acetone, phenol, xylene, toulene, methanol; (vi) Must allow import \& distribution of petroleum products.

\section{Future Recommendation}

1) The minimum standard API grade should be set for:

a. gasoline engine: $\mathrm{SG} / \mathrm{CD}$

b. diesel engine: $\mathrm{CF} / \mathrm{SF} \&$ gradually upgrade it to the global standard

2) Strong enforcement of the law to stop counterfeit/adulteration through mobile court/regulatory control authority

3) Policy Reform of Lubricant Market

4) Policy is required on proper collection \& disposal of used lubricants to protect the environment \& counterfeit products

5) Recycled/used lubricants must be banned for use as a lubricating oil

6) Adulteration of Lube oil segment should be strictly regulated \& used oil should be managed properly concerning environmental safety issues.

7) Import, blending \& marketing of lubricating oil higher than SAE 50 viscosity engine oils must be fully prohibited

8) SPM (single point mooring) has to be set up to get imported crude oil without lighter age

9) In order to avail good prices in the market, government of Bangladesh can buy crude oil 50\% through g2g \& $50 \%$ through private entities by tender

10)Rehabilitation \& expansion of our refinery to raise its production capacity

11)Currently, the BPC has a total storage capacity of 1.31 million tons of liquid petroleum products, which include diesel, furnace oil, petrol, octane, kerosene, bitumen, condensate, crude oil, etc.

12)Government should allow storage terminals to import finished products

13)Government should provide full policy support to LPG industry

14)High import cost of raw materials for LPG cylinders should be reviewed

15)Unhealthy practices such as cross filling of LPG cylinders should be regulated
16)Enforcing supervision of government organizations such as department of explosives, etc. to control industry mal practitioners

17)Framing of national policy guidelines for reducing dependency on usage of natural gas \& to encourage use of LPG in domestic, commercial \& industrial segments

18)Framing of a new policy for pass through of LPG cost to promote LPG fired power plants

19)Port development targeting effective \& efficient functional Import \& Export facilities

20)Ensuring energy security for the manufacturers \& reviewing energy prices

21)Abatement of usage of fossil fuel \& ensuring the incremental growth of clean \& modern energy for all

22)Development of LNG grid pipeline for receiving full capacity from FSRU

23)Investment of private entities (local) in national pipeline grid may be considered

\section{Acknowledgements}

I would like to thank Mr. Shihab Mahmud, Assistant Director (Reservoir \& Production), Hydrocarbon Unit, Energy and Mineral Resources Division, Ministry of Power, Energy and Mineral Resources, Bangladesh for his kind support and cooperation.

\section{References}

[1] Updated Asian Development Outlook (ADO) (September 2020), Asian Development Bank.

[2] Asian Development Outlook (April 2020), What drives innovation in Asia, Asian Development Bank.

[3] World Economic Outlook (2020], International Monitoring Fund (IMF).

[4] National Accounts Statistics Provisional Estimate of GDP 2020-2021 and Final Estimate of GDP 2019-2020; Retrieved from http://www.bbs.gov.bd/site/page/dc2bc6ce-7080-48b39a04-73cec782d0df/GDP.

[5] Annual Report on Export Promotion Bureau (2017-2018) Ministry of commerce, Bangladesh, Retrieved from http://epb.gov.bd/site/view/epb_export_data/-.

[6] Power System Master Plan (2016), Bangladesh Power Development Board, Power Division, Ministry of Power, Energy and Mineral Resources, Bangladesh.

[7] Imam Badrul. "Energy Resources of Bangladesh" 2nd Edition, 2013.

[8] Gustavson Associates, LLC, (2010), Updated Bangladesh Gas Reserve Estimation, 328-329.

[9] Monthly Report on Gas and Coal production (2021) Hydrocarbon Unit, Energy and Mineral Resources Division, Ministry of Power, Energy and Mineral Resources, Bangladesh, 1-2. 
[10] Annual Report on Bangladesh Power Development Board, (2020) Power Division, Ministry of Power, Energy and Mineral Resources, Bangladesh.

[11] Raut, Nirmal Kumar (2020), A Review of the Economic Impacts of the COVID-19 Pandemic and Economic Policies in Nepal of Retrieved from https://mpra.ub.unimuenchen.de/102778/.
[12] Monthly Report on MIS Petrobangla, (2020 \&2021) Energy and Mineral Resources Division, Ministry of Power, Energy and Mineral Resources, Bangladesh.

[13] Annual Report on Bangladesh Petroleum Corporation, (2020) Energy and Mineral Resources Division, Ministry of Power, Energy and Mineral Resources, Bangladesh. 